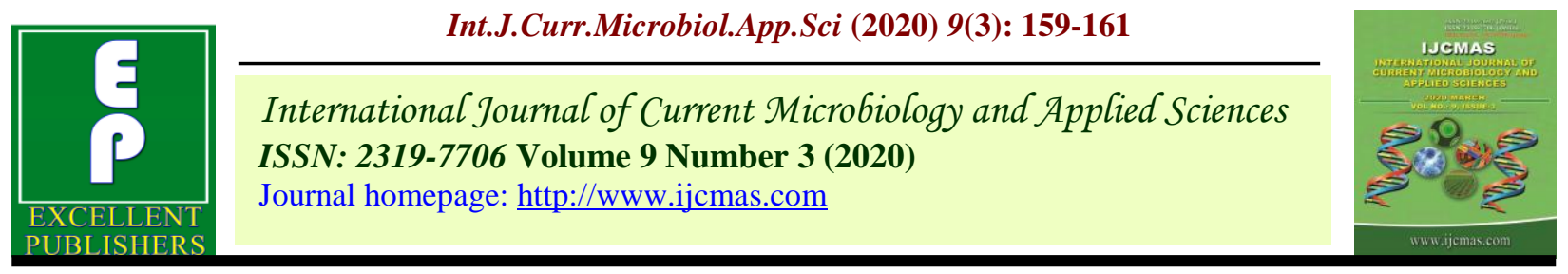

Original Research Article

https://doi.org/10.20546/ijcmas.2020.903.019

\title{
Factors Contributing for High Yielding of Cauliflower and to Find out the Constraints Faced by the Farmers in Khagaria District of Bihar, India
}

\author{
Mukesh Kumar*, Anand Pathak and Kevin Christopher \\ Department of Extension and Communication, SHUATS, Allahabad, India \\ *Corresponding author
}

\begin{tabular}{|l|}
\hline Ke y w o r d s \\
Contribution, \\
$\begin{array}{l}\text { Factors, } \\
\text { Awareness }\end{array}$ \\
\hline Article Info \\
\hline $\begin{array}{l}\text { Accepted: } \\
\text { 05 February } 2020 \\
\text { Available Online: } \\
\text { 10 March } 2020\end{array}$ \\
\hline
\end{tabular}

\section{A B S T R A C T}

The present investigation entitled "factors contributing for high yielding of cauliflower and to find out the constraints faced by the farmers in Khagaria District of Bihar" was carried out during 2017-18 120 respondents from 10 villages were randomly selected and data were collected and analysed by using appropriate statistical methods. From the study it was found that the factors contributing for increasing yield of cauliflower were sowing at proper time $(90.00 \%)$, applying organic manure $(81.60 \%)$, taking plant protection measures from time to time (78.30\%) following blanching practice $(70.00 \%)$ following irrigation schedule at proper intervals $(66.60 \%)$ and using high yielding varieties 63.60 per cent. There is a need for providing guidance on market avenues and price fluctuations from time to time to farmers. Through mass Medias like newspaper, radio and televisions, for controlling pests and diseases. Hence, there is a scope for creating awareness about the use of bio pesticides by organizing educational activities.

\section{Introduction}

Cauliflower is rich in vitamin $\mathrm{C}$ and mostly cultivated in northern India as it requires cooler climate to grow. Its annual output in India ranges at around 10 lakh tones from an area of more than 2 lakh hectares. At present, Bengal and Bihar are the largest producers of cauliflower in India followed Cauliflower is one of the popular vegetable which had its origin in cyprus and by Orissa, Uttar Pradesh,
Haryana, Madhya Pradesh, Assam and Gujarath. Cauliflower is one of the popular vegetable which had its origin in cyprus and Mediterranean coast. Cauliflower is rich in vitamin $\mathrm{C}$ and mostly cultivated in northern India as it requires cooler climate to grow. Its annual output in India ranges at around 10 lakh tones from an area of more than 2 lakh hectares. At present, Bengal and Bihar are the largest producers of cauliflower in India followed by Orissa, Uttar Pradesh, Haryana, Madhya Pradesh, Assam and Gujarat. The 
scientists of the national research Centre on plant Biotechnology and University of Hyderabad and Banaras Hindu University introduced a gene into a popular variety of cauliflower, pusa snowball K-1 and produced a variety which is resistant to diamond back moth attack. Khagaria district was selected purposively. The total net crop sown area is 1, 33902 hectares in khagaria District out of which 8, 3393 hectares under irrigation. Use of biofertilizers is mostly done in the vegetable crops. The cropping intensity being $141.49 \%$. The khagaria district comprises 7 blocks out of which the study was conducted in chautham block which is selected purposively, due to being more progressive farmers of Block. A study entitled "Adoption of farmers regarding recommended cultivation practices of cauliflower cultivation in Khagaria district of Bihar" has been conducted.

\section{Results and Discussion}

The results obtained of the study and relevant discussion has been presented under following heads.

Table.1 Factors contributing for high yielding as perceived by cauliflower growers

\begin{tabular}{|l|l|c|c|}
\hline & Particulars & Frequency & Percentage \\
\hline $\mathbf{1}$ & Taking sowing at proper time & 108 & 90.0 \\
\hline $\mathbf{2}$ & $\begin{array}{l}\text { Applying organic manure in sufficient } \\
\text { quantity }\end{array}$ & 98 & 81.60 \\
\hline $\mathbf{3}$ & $\begin{array}{l}\text { Taking plant protection measures from } \\
\text { time to time }\end{array}$ & 94 & 78.30 \\
\hline $\mathbf{4}$ & Blanching & 84 & 70.00 \\
\hline $\mathbf{5}$ & $\begin{array}{l}\text { Following irrigation schedules at proper } \\
\text { intervals }\end{array}$ & 80 & 66.60 \\
\hline $\mathbf{6}$ & Following high yielding varieties/hybrids & 76 & 63.30 \\
\hline $\mathbf{7}$ & Following recommended fertilizer dose & 50 & 41.60 \\
\hline
\end{tabular}

Table.2 Problems in production and marketing of cauliflower

\begin{tabular}{|l|l|c|c|c|}
\hline & Particulars & Frequency & Percentage & Rank \\
\hline $\mathbf{1}$ & Problem of pests & 102 & 85.00 & I \\
\hline $\mathbf{2}$ & Problem of diseases & 96 & 80.00 & II \\
\hline $\mathbf{3}$ & High cost of fertilizers & 94 & 78.30 & III \\
\hline $\mathbf{4}$ & $\begin{array}{l}\text { High cost of plant protection } \\
\text { chemicals }\end{array}$ & 46 & 38.30 & VI \\
\hline $\mathbf{5}$ & $\begin{array}{l}\text { Limited and irregular power } \\
\text { supply }\end{array}$ & 46 & 38.30 & VII \\
\hline $\mathbf{6}$ & Poor transportation facilities & 94 & 36.60 & VIII \\
\hline $\mathbf{7}$ & Fluctuations in the prices & 92 & 76.66 & IV \\
\hline $\mathbf{8}$ & Exploitation by the middleman. & 86 & 71.66 & V \\
\hline
\end{tabular}


A perusal of Table 4.4 and reveals the factors contributing for increasing yield of cauliflower were sowing at proper time $(90.00 \%)$, applying organic manure $(81.60 \%)$, taking plant protection measures from time to time $(78.30 \%)$ following blanching practice $(70.00 \%)$ following irrigation schedule at proper intervals $(66.60 \%)$ and using high yielding varieties 63.60 per cent.

Above table shows that the problem of pests Problem of diseases was the foremost problem followed by High cost of fertilizers followed by Fluctuations in the prices followed by Exploitation by the middle man. Followed by High cost of plant protection chemicals followed by Limited and irregular power followed by supply Poor transportation facilities.

It can be concluded from above study that majority of the factors contributing for increasing yield of cauliflower were sowing at proper time $(90.00 \%)$, applying organic manure $(81.60 \%)$, taking plant protection measures from time to time $(78.30 \%)$ following blanching practice $(70.00 \%)$ following irrigation schedule at proper intervals $(66.60 \%)$ and using high yielding varieties 63.60 per cent. Problem of pests Problem of diseases was the foremost problem followed by High cost of fertilizers followed by Fluctuations in the prices followed by Exploitation by the middleman. Followed by High cost of plant protection chemicals followed by Limited and irregular power followed by supply Poor transportation facilities.

\section{References}

Anitha, B., 2004, A study on entrepreneurial behaviour and market participation of farm women in Bangalore rural district of Karnataka. M. Sc. (Agri.) Thesis, University of Agricultural Sciences, Bangalore.

Dhamodaran, T. and Vasantha Kumar, J., 2001, Relationship between selected characteristics of registered sugarcane growers and their extent of adoption of improved sugarcane cultivation practices. Journal of Extension Education, 12(2): 3138-3143.

Karpagam, c., 2000, A study on knowledge and adoption behaviour of turmeric growers in Erode district of Tamil Nadu state. M. Sc (Agri) Thesis, University of Agricultural Sciences, Dharwad.

Palaniswamy, K. and Sriram, M. S., 2001, A scale to measure extension participation of farmers. Indian Journal of Extension Education, 19: 325-328.

Shashidhar, D. N, 2004, A study on influencing factors and constraints in drip irrigation by horticulture farmers of Bijapur district of Karnataka. M. Sc. (Agri.) Thesis, University of Agricultural Sciences, Dharwad.

Sunilkumar, G. M., 2004, A study on farmers knowledge and adoption of production and post harvest technology in tomato crop of Belgaum district in Karnataka. M.Sc. (Agri.) Thesis, University of Agricultural Sciences, Dharwad.

\section{How to cite this article:}

Mukesh Kumar, Anand Pathak and Kevin Christopher. 2020. Factors Contributing for High Yielding of Cauliflower and to Find out the Constraints Faced by the Farmers in Khagaria District of Bihar, India. Int.J.Curr.Microbiol.App.Sci. 9(03): 159-161. doi: https://doi.org/10.20546/ijcmas.2020.903.019 